\title{
Effect of fertility levels and biofertilizers on growth and yield of cowpea on sandy loam soil of Rajasthan
}

\section{J.S. MEENA, H.P. VERMA AND PINKI PANCHOLI}

Received : 28.10.2014; Revised : 15.04.2015; Accepted : 23.04.2015

MEMBERS OF RESEARCH FORUM:

Corresponding author : J.S. MEENA, Department of Soil Science, S.K.N. College of Agriculture, S.K.N. Agriculture University, JOBNER (RAJASTHAN) INDIA

Email: hppersoya.p@gmail.com

Co-authors :

H.P. VERMA, Department of Agronomy, College of Agriculture, S.K.N. Agriculture University, JOBNER (RAJASTHAN) INDIA

PINKI PANCHOLI, Department of Soil Science, College of Agriculture, S.K.N. Agriculture University, JOBNER (RAJASTHAN) INDIA

\begin{abstract}
Summary
A field experiment was conducted during Kharif season of 2013 to know the effect of fertility levels and biofertilizers on growth and yield of cowpea on sandy loam soil of Rajasthan. The experiment consisted of four treatments of fertility levels (control, $100 \%$ RDF, $75 \%$ RDF+VC @ $2 \mathrm{t} / \mathrm{ha}$ and $100 \% \mathrm{RDF}+\mathrm{VC} @ 2 \mathrm{t} / \mathrm{ha}$ ) and four levels of biofertilizers (control, Rhizobium, PSB and Rhizobium + PSB) thereby making sixteen treatment combinations tested in factorial Randomized Block Design with three replications. Results indicated that application of 100 per cent RDF+VC @ $2 \mathrm{t} / \mathrm{ha}$ significantly increased the plant height, number of branches per plant, chlorophyll content, total root and effective root nodules, fresh weight and dry weight of nodules, leghaemoglobin content, number of pods per plant, number of seeds per pod, seed, straw and biological yield and remained at par with the application of 75 per cent RDF+VC @ $2 \mathrm{t} /$ ha over control. However, application the test weight and harvest index unchanged under different fertility levels. Results further indicated that inoculation of Rhizobium and PSB significantly increased the chlorophyll content, total root and effective root nodules, fresh weight and dry weight of nodules, leghaemoglobin content, number of pods per plant, number of seeds per pod, seed and biological yield. However, inoculation of Rhizobium and PSB significantly increased the plant height, number of branches per plant and straw yield over the rest of treatments. However, the test weight and harvest index remained unchanged under different levels of biofertilizers.
\end{abstract}

Key words : Cowpea, Fertility levels, Growth, Rhizobium, PSB, Yield

How to cite this article : Meena, J.S., Verma, H.P. and Pancholi, Pinki (2015). Effect of fertility levels and biofertilizers on growth and yield of cowpea on sandy loam soil of Rajasthan. Asian J. Soil Sci., 10(1): $55-58$. 